\title{
Managing urban riverscapes: towards a cultural perspective of land and water governance
}

\author{
Meike Levin-Keitel \\ Institute of Environmental Planning, Leibniz University of Hanover, Hanover, Germany
}

This is an Author's Accepted Manuscript of an article published in Water International 39 (2014), S. 842-857, available online at: http://www.tandfonline.com/10.1080/02508060.2014.957797. C Taylor \& Francis

\begin{abstract}
Urban riverscapes are facing diverse demands concerning riparian uses, ecological, economic and social functionalities, and aesthetic questions. One of the main challengestoday is the implementation of an integrative perspective on riverscapes to overcome the horizontal frontiers of traditional water management (water governance) and urban planning (land governance). Led by the theoretical framework of planning culture, the article shows the different rationalities and governance approaches from a cultural perspective. Finally, two quite different local planning cultures are outlined to illustrate the cultural variety with which the challenges of sustainable urban riverscapes are managed.
\end{abstract}

Keywords: urban river management; organizational culture; land and water governance; Germany

\section{Focusing on urban riverscapes}

Rivers have always played a crucial role in human activities, e.g. the founding of settlements on riverbanks, the use of temporarily flooded areas for agricultural food production, or their use as strategic barriers of defence. On rivers, goods for trade were transported, the river water was necessary for the development of different techniques of traditional handicraft, and it simultaneously served as a fresh water supply and wastewater disposal. Nowadays, focusing on urban riverscapes includes being confronted by some of these issues (albeit slightly modified), as well as the multiple additional demands on the river water itself (in terms of quality and quantity) and on its riparian land uses and their diverse influences (in terms of the cycle of substances, interdependence between these uses and the river ecosystem, their spatial impact, the consequences of societal changes, etc. (Levin-Keitel, 2014)). Especially in urban areas, where space by the river is limited and numerous diverging interests are articulated, these demands and peculiarities are gaining a controversial dimension.

\section{Multiple policy perspectives and their integration}

Even though the city level is neither typical for nor representative of river management in general (such as the scale of international river associations, river basins or regional catchment areas), the questions of integration and integrated implementation occur at the local level, often in a project-based approach. Accordingly, in the last decade urban riverscapes have re-emerged as one of the central issues of European urban planning and development. Due to different driving forces, urban riverscapes come to the fore of diverse stakeholders, demands and functionalities, and the promotion of various laws, directives, programmes and policies. This includes, in particular, European guidelines such as the European Union Water Framework Directive, the current discussion about urban climate change adaptations, and former industrial sites in inner cities being redeveloped. These diverse interests mean that the idea of an integrative perspective represents a significant challenge, which consequently raises considerations about aspects of traditional water management, such as water quality and flood management. Furthermore, only respecting and considering multiple demands, including economic interests, ecological aspects, historical significance, sociological conditions or infrastructural perspectives, allows one to develop sustainable urban riverscapes. Certainly, one can identify a number of policy sectors articulating river purposes in general (Figure 1); but as local circumstances play an important role, the art of management lies in juggling the appropriate purposes without underestimating their local interdependence. This shows a first insight into the complexity and enormous challenges that have to be met in managing urban riverscapes. Each policy sector has its eligibility, each sector formulates essential needs and demands, and an integrative perspective indispensably has to understand and tolerate these specific socially constructed views by accepting riverscapes as product of many separately made decisions. Or, as Biswas (2004) wrote concerning integrated water resource management (IWRM)1: 'water problems have become multi-dimensional, multi-sectoral, and multi-regional and filled with multi-interests, multi-agendas, and multi-causes, and which can be resolved only through a proper multi institutional and multi-stakeholder coordination' (p. 249). This article focuses on the indispensable integrative part of managing urban riverscapes. This involves the different facets of water and its governance from a land perspective as well as from a water point of view. Being far off just a 'management problem', the challenge of an integrative approach lies in overcoming diverse rationalities 


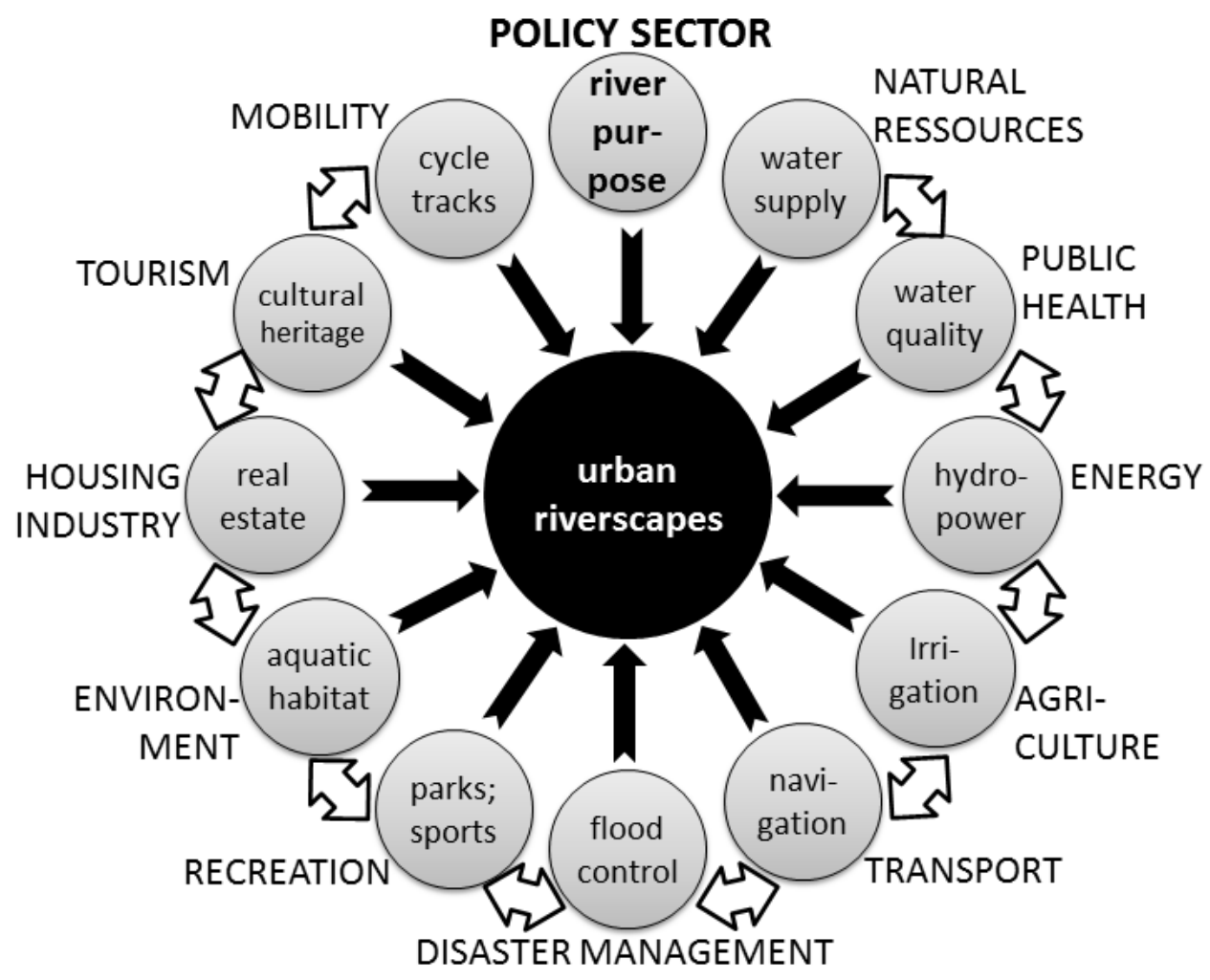

Figure 1. Multiple policy sectors articulating river purposes.

and habits, combining different legal, formal and informal frame conditions, creating winwin situations whenever possible and/or establishing so-called intercultural learning processes to overcome not only horizontal cultural frontiers. Core questions are as follows:

- What is the role of culture (like norms and values) in integrated planning processes of urban riverscapes?

- How can these dynamic cultural complexes be defined and analysed in terms of key aspects of organizational cultures?

\section{Empirical studies and methodological approach}

This article builds up on two empirical case studies being part of a major $\mathrm{PhD}$ project treating cultural perspectives of integrated planning processes in theory and practice. The two case studies: Ratisbon (Regensburg) and Nuremberg (Nürnberg), are situated in Bavaria in southern Germany. Ratisbon has 138,000 inhabitants (Stadt Regensburg 2012, p. 10) and is well known for its medieval inner city and picturesque riverscape. Nearly all parts of the inner city have been a UNESCO World Heritage site since 2006 (United Nations Educational, Scientific and Cultural Organisation (UNESCO), 2014) and an authentic Bavarian style of living is presented to the numerous tourists from all over the world (nearly 1 million nights per year; Stadt Regensburg 2012a, p. 9). Three rivers characterize the city substantially: the Danube, the Regen and the Naab. While the Naab flows into the Danube before crossing the urban realm, the Regen joins it from north. The Danube itself is split up into three branches in the city area, one navigable canal and two more or less naturally river branches. As result, three islands and many (medieval) bridges are part of the city's image. In general, Ratisbon is quite vulnerable to hazards of flooding, the major reason to rethink the urban riverscapes. Nuremberg is characterized by nearly 500,000 inhabitants and a population density of 2655 inhabitants per km2 (Stadt Nürnberg 2012, n.p.). Sandstone, small streets and houses as well as few open spaces dominate the inner city, and apart from some interesting touristic destinations, the demands of the local inhabitants are on the agenda (e.g. qualitative open spaces, transport and mobility). The river Pegnitz runs through the city feeding a huge sea in the inner city, the Wöhrder See, and creating inhabited islands in the river itself. Apart from the sea situation, water is not very visible in the inner city. In the 1970s, the management of Nuremberg's floods found technical solutions in forms of canals and banished all water from the open space. This is why nowadays water must be rediscovered as element in the inner city. 
A comparison between the two case studies in Ratisbon and Nuremberg is limited neither to their urban morphology nor to their later history in managing riverscapes, nor to their intentions to turn to their riverscapes nowadays. Here the planning process of an integrative perspective on urban riverscapes has focused on drawing conclusions on the cultural perspective of integration processes as well as the organizational cultures of the involved actors. Two integrated urban development plans have been extensively researched: in Ratisbon the riverscape concept (WWA \& Stadt Regensburg, 2010) and in Nuremberg the urban development concept water (Stadt Nürnberg, 2012b), in order to work out the actor's opinions and rationalities, interpretations of socially constructed realities, sector-based instruments and their implementation, as well as their specific language and characteristics. Methodologically, these two very complex planning processes where analysed by a diverse mix of methods of structured expert interviews, participating observation, and local document research, from where the information and data are taken. On the one hand, Ratisbon and Nuremberg have been chosen as case studies because of their similar point of departure, for instance their identical legal bases, the same organizational structures of the involved institutions and the same formal planning system. On the other hand, both cities show differences in how they handle and manage the urban riverscapes, beginning with the perception of water in the inner cities, the leadership of the integrated planning process (the water management agency in Ratisbon and the local planning authority in Nuremberg), and the common ground from which they started. This was intended to make the cultural differences visible that are not simply part of another planning system (as in European comparative research for instance) or differing legal conditions (like in different German states). So after having briefly introduced urban riverscapes and having pointed out the high complexities and interdependencies of their management, this article calls on the cultural perspective of land and water governance. In the first step, the concept of governance as an actor-centred view is represented and applied to urban riverscapes, revealing the limits of this concept by considering perceptions and interpretations of problems and solutions. To overcome these rationalities, perspectives and aforementioned horizontal frontiers, the theoretical framework of organizational culture is represented in a second step. Using culture as an analytical framework, the integrated planning processes of urban riverscapes are presented by their visible artefacts, organizational culture and planning context. Following this, different cultural imprints are illustrated, with special focus on two different modes of governance: water governance and land governance. The article ends with a plea for a cultural perspective on integration processes and the added value it brings.

\section{Just a question of governance - an actor-centred view}

Taking into account the multi-thematic approaches of urban riverscapes, the need for a certain kind of management becomes evident. As the local government or even the public sector is not the only controlling actor when urban riverscapes are considered, other ways of steering and managing such sites come to the fore. Generally, governance theory is divided into three different currents: the analytical purpose of steering and decision-making, the normative purpose of good governance, and the descriptive purpose where the content plays a crucial role (Benz, Lütz, Schimank, \& Simonis, 2007). Using governance theory as an analytical framework to describe contemporary planning processes also means considering not only the government but also a whole ensemble of actors, institutions and management (Benz et al., 2007; DiGaetano \& Strom, 2003; Fürst, 2001; Nuissl \& Heinrichs, 2011). In particular, environmental governance was meant to be the solution for all issues and measures for avoiding harmful effects on the environment (Driessen, Dieperink, van Laerhoven, Runhaar, \& Vermeulen, 2012). In the urban riverscapes, possible conflicts become visible: multiple actors at all levels with specific rationalities are trying to reach consensus on land and water issues in a particularly small place: the urban riverscape. Table 1 outlines the main actors in all different policy fields with their kind of rationality in the sense of an operating logic of their means and ends as well as their anchoring on different spatial and administrative levels. The contents are based on the findings of the two case studies of Ratisbon and Nuremberg. Due to the high degree of contextuality in urban planning and development, this overview just helps to illustrate the complexity of such governance approaches and is no claim to universality. Regarding this diversity of stakeholders, their specific rationalities on how they perceive the urban riverscape and the objectives they come along with, a highly rational way of steering the development of urban rivers seems to be desperate. Especially when it comes to the point where neither a single institution nor a single rationality is powerful enough to be able to predominate over other stakeholders, institutions or rationalities. Moreover, it must be held that there is not one institution coordinating riverscapes at any level; in fact, it is more or less like an overlapping mosaic of institutions and organizations' competence.2 How then is it possible to steer these different views and actors? What does integration in this very complex aggregation of actors, power and discourses mean? Making integration a subject of discussion means not remaining on purely normative projections and notions of what seems to be 'right' or 'wrong'. In fact, it is rather a question of tapping into the available potential of integrating different demands at the urban riverside. The aim is not a comprehensive plan including every single probability proven by facts and figures, but an integrative planning approach, considering uncertain conditions and an at present unpredictable future (Mitchell, 2005). Integration can be seen as a creative process for structuring a mosaic of different layers for the optimum interplay, so the first point is to accept this very complex and highly polyrational steering process. Even if all available facts and every actor involved are integrated, the result of planning processes in urban riverscapes is not predictable in all details (Billé, 2008). Consequently, it is not surprising that the management of diverse different rationalities on various levels is highly context-bound. As Rittel and Webber (1973) stated in their theory of wicked problems in spatial planning, policy problems cannot be definitely described because they refer to public goods with no objective definition of equity, so one cannot talk about an optimum solution. So, what is called a solution only fits in one specific context and can become 
obsolete immediately. The incontestable aspect is that planning processes are highly context-bound to the extent that they call for individual solutions and open process designs. This explains why urban riverscapes look different in New 


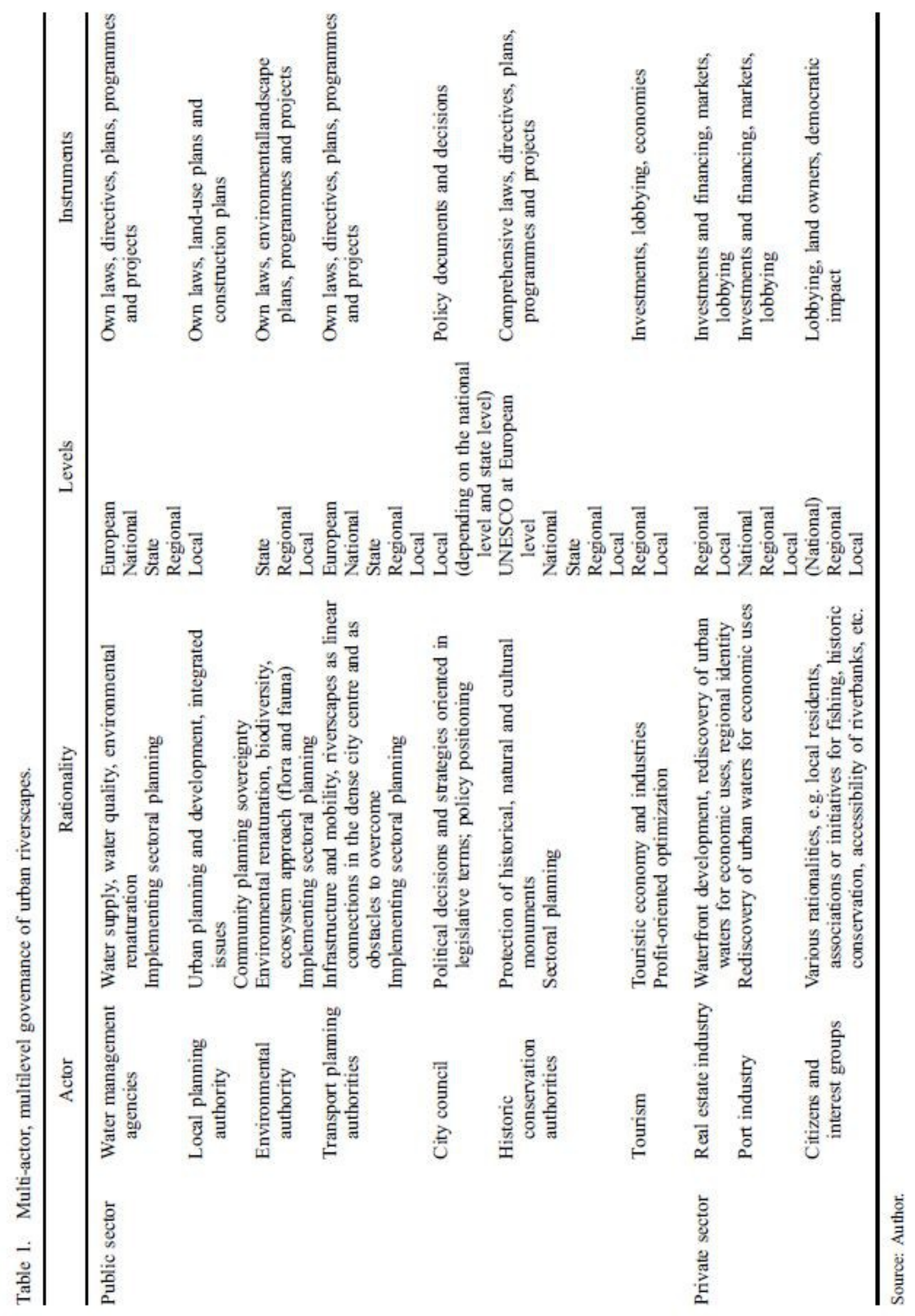


York and Berlin, why the process design of developing urban riverscapes occurs differently in Paris and Hamburg; or, as Driessen et al. (2012) claim, the 'extent of multi-actor, multi-level governance determines variation in the perception of problems and solutions' (p. 145).

\section{The role of culture in an actor-centred approach}

The question arises of how these context-bound differences in managing urban riverscapes can be analysed and what this means for their development. In a phenomenological approach, however, even if one compares the planning process of two urban riverscapes in two cities like Nuremberg and Ratisbon - with the same institutional organizations, identical legal conditions and the same groups of actors involved - significant differences can be noted. At this point, a cultural dimension of planning processes and an awareness of culture as a matter of fact in planning processes becomes apparent.

\section{Theoretical derivation of a cultural perspective on integration processes}

From the perspective of planning theory, this cultural turn can be considered as an approach to gaining a deeper understanding of planning processes. The planning culture as a whole is derived from two different aspects: (1) by recognizing the variety and the differences of planning institutions and practices (Friedmann, 2005) or (2) spatial planning as a cultural act itself (Nuissl, 2008). After the often claimed 'communicative turn' (Healey, 1996) in planning theory, a multi-actor, multilevel governance approach represented a kind of shift from a highly rational practice of management to a planning process determined by communication, cooperation and participation. With the communicative turn, the focus of analyses was set on the actors of a system, an actorcentred approach (Fürst, 2007; Nuissl \& Heinrichs, 2011). However, a general gap between the theoretical interpretations and real planning practice can still be stated. Dependent on an authority's behaviour and cooperation, and willingness to communicate, the involvements in waterside projects differ. Therefore it is not all about institutional arrangement and the organizations involved, but another important factor is outlined: the cultural orientation of the involved actors and the planning culture they establish and maintain (Knieling \& Othengrafen, 2009; Othengrafen, 2012). Building up on the definition of culture by Gullestrup (2009) the concept of culture can be transferred to actorcentred integration processes:

Culture is the world conception and the values, moral norms and actual behaviour - as well as material and immaterial results thereof - which people take over from a past generation; and which make them different in various ways from people belonging to other cultures. (p. 4)

So, the cultural perspective is about a society's cultural imprint, meaning the cultural behaviour of all involved actors, different cultural techniques, cultural attitudes and their interaction with each other. In the literature, planning culture is often used with terms like cultural framing (Ernste, 2012), as culturized planning practice (Othengrafen 2010) or planning culture as an underlying concept expressing the practice of planners (Reimer \& Blotevogel, 2012, p. 14). Consequently, 'Planning systems and planning practice are part of the culture of a society' (Nuissl, 2008) and the other way round, planning processes produce, develop and maintain the culture of a society by the way in which cities are designed, developed and influenced. Nevertheless, culture is ambiguous, complex to analyse and to identify if it is not taken as a normative ideal in the sense of a better/ good planning culture. The aim of this article is not about identifying how planning should be or should theoretically come out. This implies not sticking to one truth but rather explicitly emphasizing the perception and interpretation of single actors and groups of actors.

\section{Planning culture as analytical framework for urban riverscapes}

How can these characteristics lead to an analytical framework for the analysis of urban riverscapes? The aim is to understand the developing process of integrated riverscape management, especially the different perspectives on the river, ranging from sectoral logics of action and self-conceptions to common orientations and the shared learning process (innovation ability). The following analytical framework builds on a theoretical planning culture model of Levin-Keitel and Sondermann (2014). These authors identify a core societal context, as planning is part of a society's culture, framing all integration processes and playing a key role in the comparison of planning cultures in international or European contexts. Apart from this omnipresent societal dimension, three main analytical levels representing cultural elements are identified:

- Visible artefacts represent the products and results of urban planning and development, implying spatial plans and concepts as well as their specific implementation in the form of spatial structures and functions.

- Planning context signifies the setting in which planning processes take place, including the main structures and frames of the planning conditions. Here the structures of the institutional and legal system, as well as formal and informal rules and procedures, stand in the focus of the reflection. 
- Organizational cultures denotes an organization's values and norms, its specific processes of learning and socialization as inter-individual patterns, its self-conception and game rules. These cultural elements can be stated amongst a single group of actors and additionally between different groups of actors, making it even more complex and interesting.

First, visible artefacts include in particular all spatial plans and concepts, as they can be seen as a specific language where present values and norms are manifested. Furthermore, the content of these plans and concepts mirrors the contemporary spirit of spatial planning by identifying the most important challenges and the field of action, based on (cultural) interpretations of what is important and what is not (Othengrafen, 2012). In the last 20 years, many cities have rediscovered their urban riverscapes, and water and rivers have played a crucial role in integrated city development plans again after having been ignored for decades. Nowadays the implementation of these ideas can be re-found in the urban space. Therefore, secondly, contemporary spatial structures and functions in the inner city have to be read as cultural artefacts as well. They are so to speak cultural witnesses in stone: on the one hand, these structures and patterns can be seen as an expression of the human-made plans and development of former times; and, on the other hand, they are the starting point for every (spatial) activity now and in future times. Ideas, plans and concepts become reality they become de facto existing structures and patterns and symbolize an expression of culture. These visible artefacts determine to a high degree contemporary planning culture, including which demands have to be integrated - whether flood protection is needed, how citizens can be involved, etc. - and, furthermore, questions of land use - whether to place settlements in a flood-risk area, how to combine or to separate different land uses, etc. The planning context is about the planning conditions, such as formal and informal rules and the institutional planning system. It covers the specific framing conditions of spatial planning, unlike the visible artefacts that are a result of planning endeavours as well as of other non-planning-related developments. This planning context implies legal conditions such as the approval procedures of constructions in the flood-risk areas or sectoral legal demands, administrative and organizational rules such as hierarchical positions, and the actors who are to be involved in legally binding processes. Informal and formal rules and arrangements play an important role in planning processes as well, as they allow enough flexibility for actions and routines. The planning context is the central point of departure for actors in the planning processes and their perceptions, interpretations, judgments and actions. For a further analysis of this part of planning culture, compare the already established system-related analysis in spatial planning, where numerous elements of scope are already discussed (Ernste, 2012; Othengrafen, 2012; Reimer \& Blotevogel, 2012). Organizational cultures involve all individuals and groups acting on the local, regional or national level. This includes the local planning authorities and public services, citizen stakeholder groups or economic actors. Focusing on the specific constellations of and interactions between the actors (Fürst, 2007; Moss, 2009; Nuissl \& Heinrichs, 2011), this part of a planning culture is about individual perceptions, institutionalized interpretations and their resulting actions. The consideration of all involved stakeholders in planning processes is by no means new or innovative, but represented by Scharpf (2000) and implemented within the governance analysis. The new and specific cultural aspect of these interactions and constellations is to regard different actor groups as organizations with an explicit organizational culture. The term 'organization' is used here in a very broad sense - an organization is a group of actors more or less institutionalized, ranging from the local planning authority or water management agencies to single-purpose citizens' initiatives or clubs and associations. Organizational cultures can be defined as the result of processes of learning and socialization processes under a certain umbrella of an organization. These are based on invisible concepts such as values and norms, and lead to:

- the formation of common patterns of orientation ending up in central premises of action;

- the development of shared informal rules; and

- the characterization of the self-conception of an organization (Schein, 2003).

From an external perspective, organizational cultures are noticed by visible perceptas, namely the visible artefacts of the analytical model presented above. The concept of the organizational culture is based on the theoretical cultural approach of Schein (2003). This concept was implemented by Faust (2002) on public services and by Othengrafen (2012) on spatial planning. As public services are responsible for spatial planning at diverse levels of planning, this concept seems appropriate for the analysis of the cultural dimension of spatial planning.

\section{Cultural perspective of land and water governance}

The aforementioned analytical framework is now implemented in the two case studies on the trail of local planning cultures, with special interest in the organizational cultures of water management agencies and local planning authorities in Ratisbon and Nuremberg. The following information and data are mostly based on the expert interviews made on site (if not cited differently). Visible artefacts contain the spatial plans and concepts within the two cities of Ratisbon and Nuremberg. In both cities one can observe a high number of formal and informal plans and programmes, concepts and politics in different coalitions of actors, ranging from area-based integrated development plans (e.g. for the western city, for urban redevelopment) to thematic or sectoral concepts for the whole urban area (e.g. a mobility plan or programmes for cultural heritage). However, both cities are very vivid concerning spatial development, being confronted with several pressing challenges. Additionally, both cities' societies are discussing these concepts and plans 
intensively in local newspapers, discussion forums or participation activities. Furthermore, the structure and the functions of the inner cities, as a second part of the category of visible artefacts, are comparable as well. Both cities are characterized by a medieval inner city, in the outer scope of flood areas. This includes a rather densely built environment with a potential lack of open space already. In both cases, different demands of restructuring the urban riverscape meet the challenge of an already compactly built city structure. The rivers - in Ratisbon the Danube, Naab and Regen, and in Nuremberg the Pegnitz - flow through the inner city, creating inhabited islands as well as zones of natural protection. Even if Ratisbon is, for instance, potentially at danger of floods (because of its spatial exposure) and Nuremberg is more affected by droughts (and invisible water in the city area), the riparian uses and the complex planning processes for restructuring and managing the riverscapes are comparable. Apart from the detailed table of multi-actor, multilevel governance (Table 1), some supplementary information has to be added. For the two chosen case studies, the planning context is nearly identical, as both cities are situated in Europe (European Directives:

FRD, WFD), in Germany (national framework: WHG), and in Bavaria (the same federal state meaning the same water legislation: BayWG) with the same administrative and organizational background of decision-making. The planning context of the case studies is mainly predetermined by two actors and their legally binding instruments: the water management agencies and the local (urban) planning authorities. Both of them do havean integrative approach in space and time, and both are part of the public services acting in line with their proper water purpose legislations, which have binding consequences for the other governmental services and the private sector (Von Haaren \& Moss, 2011; Wiering \& Immink, 2006). Water management agencies are, by WHG §38(3), in charge of the river itself and the sufficiently broad stretches of the riparian uses. Here the water management agencies (in representation of the Bavarian Free State) work as contact persons on a regional scale, not only within the city boundaries. Their instruments (river basin management plans etc., WHG §83) are binding; they plan and implement with their own financial and human resources. For construction they need a permit from the city. Local (urban) planning authorities are part of the city administration and very close to politics, as their leader is elected politically (city council). Their aim is city development and a balance of ecological, economic and social demands within the city area. Their perspective on the riverscape is characterized by land uses, riparian uses or the obstacle of the river in the city area. Their instruments are binding for public services (land-use plans, BauGB $\S \S 5-7$ ) and for all citizens (construction plans, BauGB $\S \S 8-10$ ). The urban planning authorities plan, but the implementation lies in the hands of private investors or sectoral planning agencies. They are not able to implement projects on the river by themselves, as they do not possess their own financial resources. Therefore, even if there are some regulations within the management of riverscapes that direct them to fulfil the demanded cooperation between the water management agencies and the urban planning authorities, there is still a lot of freedom of interpretation as to how this cooperation can be filled with life. Table 2 identifies the two different rationalities water management agencies and local planning authorities display by their objectives, main interests, intentions, planning focus and temporal and financial resources. Rationalities are hereby seen as rational conclusions of their mission. In the following, the organizational cultures of water management agencies, as well as urban planning authorities in Bavaria, are drawn as they were analysed from the two case studies. Of course, these following arrangements are not representative for all water management agencies and urban planning authorities; furthermore, they give an idea about what the organizational culture is about and to where the specific cultural imprint leads. Both organizational cultures are described, analysed and abstracted by four main categories, evolving from the empirical analyses:

- important traditions and contemporary orientations;

- concepts of democracy and justice;

- effectiveness of their outputs; and

- self-conception and ability to innovate.

Table 2. Comparison of governance of water management agencies and urban planning authorities.

\begin{tabular}{|c|c|c|}
\hline & Water management agencies & Urban planning authorities \\
\hline Governance mode & Water governance & Land govemance \\
\hline Objective & Water resources (multifunctional) & Land use (multidisciplinary) \\
\hline Main interest & Safety of the city & Urban development and design \\
\hline Intention & $\begin{array}{l}\text { Good ecological quality (or potential } \\
\text { of water bodies) }\end{array}$ & $\begin{array}{l}\text { Principles and aims of regional } \\
\text { policy }\end{array}$ \\
\hline Planning focus & $\begin{array}{l}\text { Single projects in regional scales, } \\
\text { spatial vision of the river }\end{array}$ & $\begin{array}{l}\text { Comprehensive and strategic } \\
\text { (whole city-area) }\end{array}$ \\
\hline Time schedule & $\begin{array}{l}\text { Standardized European Union-wide } \\
\text { time schedule }\end{array}$ & $\begin{array}{l}\text { Open, different spatiotemporal } \\
\text { process }\end{array}$ \\
\hline Resources & $\begin{array}{l}\text { Comparatively good financial and } \\
\text { personnel resources }\end{array}$ & $\begin{array}{l}\text { Comparatively less financial and } \\
\text { personnel resources }\end{array}$ \\
\hline
\end{tabular}

Source: Author. 
The water management agencies of the two case studies do have an implementationoriented governance approach, as already mentioned above. This is characterized by the following:

- Their interactions are based on federal water law with the aim of ensuring water supply, to minimize flood risk and to develop nature-like environments (BayWG $\$ \$ 22-23$ ). In former times, the water management agencies were much more technically oriented, being specialists in the construction and measurement of rivers and seas. This basis on natural science techniques to survey, measure and control water in general has undergone a paradigm shift in the last 30 years (Driessen et al., 2012; Gleick, 2000; Hartmann, 2010; Molle, 2008). The keywords of this development are the uncontrollability of nature and the failure of technological solutions, unpredictable changes, such as climate change, demographic changes, etc. Contemporary orientations in the water sector are characterized by a shift from purely technological and natural scientific solutions to a coordination of societal needs. The questions are not only what is technically feasible and in how far it is the best solution, but also what kind of land use is desired, how flood security can look under these circumstances, and how society wants to live. In other words, values and norms are threatened as well as technical solutions. Here the second point of the analyses is already introduced. Of course, as a public service, the water management agencies are integrated in the democratic machinery.

- They also belong to the federal administration, to an elected ministry, legitimated by politics, laws and assessments. Furthermore, they are obliged to organize public participation. Nevertheless the question of justice remains. How much open space

by the river has to be provided to the general public? Do water management agencies take care of the common goods? And, in terms of flood-risk management, how are citizens' demands to be integrated? Is it just that a couple of citizens refuse to construct a protective wall in front of their house, but at the same time call for help in situations of flood catastrophes (putting firemen in danger as well)? The clash of security needs and participation doubtlessly demands a balancing act and remains one of the central issues of water management agencies in future.

- In terms of effectiveness, water management agencies achieve rather good outputs, especially as the achieved quality becomes obvious: water supply is guaranteed whenever water is needed, flood security is proven by every flood and so is the quality of the built and organitational measures. With regard to renaturation, results can be analysed by red-listed animals or plants or other natural science proofs.

- As sectoral planning agencies, they possess high self-confidence, further strengthened by numerous developments and versatile competence on all levels. In the past, the water management agencies already played a crucial role: water supply and water disposal as basic needs in the cities, making rivers and seas navigable for economic uses, flood security for densely populated and valuable regions, codetermination of the image of the cities, etc. This importance was reinforced by additional tasks, e.g. by the water framework directive and national/federal implementation. The reorganization of the water management agencies led to a very modern, open-minded and innovation-friendly authority, on the one hand acting in area-based teams on all levels and scales and, on the other hand, in thematic expert teams transferring new knowledge and experiences directly in all levels. Another asset is the medium size of the water management agencies (about 2000 people), which supports the transfer of ideas, visions, as well as problems, challenges and threats.

Nevertheless, in both agencies, after a time of warming up and getting to know each other, the interview partners were able to draw a greater vision of the rivers' development and the urban water development, which has never been written down before, but which has been created by consensus in the specific water management agency. It is, so to say, a part of the invisible underlying core assumptions. In comparison with this, the organizational culture of the urban planning authorities can be portrayed by the logic of land governance: 
- They operate from a territorial perspective, following the riparian uses towards the water. As urban planning and development aim for an integrative perspective, diverse demands have been collected, evaluated and a decision on the most expedient solution has been made, so one can state that all relevant aspects are under consideration. Yet, as continuous changes (climate change, demographic change, structural change) and modifications in the (spatial) needs and demands of a society evolve permanently, urban planning always remains in a discursive approach between many possible solutions. Apart from the legally binding instruments, the power of spatial planning in general is based on persuasive instruments, by arguing and convincing the involved actors to implement what planners have planned before (Hutter, 2007).

- Concerning the concept of democracy and justice, unquestionably the urban planning authority is part of the cities' administration, led by local politicians (city council), with its proper legal basis and binding instruments. So, the democratic legitimation is given by the elected city council and key decisions were prepared by the administration, but still the decision lies with the responsibility of politics. Here, the two case studies differ obviously. While in Ratisbon the main issue of the riverscape management, flood protection, is not a political debate in the urban society, in Nuremberg the accessibility of the river (as the main issue here) is politically implicated. The situation gets even more complex by recognizing that the urban planning authority is not only one administrative body in the city administration, but (differing from city to city) consists of different departments (e.g. the urban development department, the urban planning department, environmental planning department, the construction department), which are in most cases led by representatives of different political parties. In this sense, already within one organization, a far-reaching negotiation process has to take place, and is not always in consensus about how the urban environment (and especially the urban riverscapes) is to be managed, designed or treated.

- This is part of an explanation as to why the effectiveness of their outcomes is hard to define, or nearly impossible to judge. First of all, the question arises: effective for what? Is contemporary land use effective for future generations (regarding the theory of sustainability)? Is the use of the ground effective or not? In general, spatial planning has to deal with this problem of evaluation. There are no real accurate criteria with which to judge the outcomes of spatial planning (Rittel \& Webber, 1973). For instance, is a consensus in planning processes worth more than a result in disharmony (well-knowing that some topics are diametric and real consensus cannot be created)? How do we judge a communicative planning process? On a very low level this is possible, e.g. if there has been a debate about the topic at all or if different demands have been considered. But to decide whether planning has been effective or not gets even more complicated because planning authorities are not the implementing bodies (Einig, 2012; Weith, 2007).

- This is possibly reflected in the urban planning authority's self-conception as well. As the authority is not acting like one organization with one organizational culture and one obvious target to implement, the self-conceptions vary significantly (as they also do in the two case studies). On the one hand, urban planning authorities can be crucially influenced by political statements, positioning and strategies (as in the example of Nuremberg), and, on the other hand, the collaboration between different departments of the same administrative bodies has to be checked out and an informal, inter-departmental integration is a precondition of further planning. But planning is normative; planning implies the handling of societal values and norms about how the urban society wants to live in future. There is no 'right' or 'wrong', there is a kind of debate, consensus or not, and many other demands that have to be respected and considered. Additionally, urban planning authorities are seen as advocates for the common good and public welfare. So, all in all, the urban planning authorities are characterized by a hybrid situation between high claims of coordination, the evaluation of different demands and speaking for the common good, in a cultural context of more than one organization (department), paired with weak instruments and no possibilities for implementation. Their self-confidence depends very much on the organizational leadership, the functions and tasks they occupy as well as their freedom of decision-making and their willingness to be involved.

Shown by the examples of Ratisbon and Nuremberg, the different organizational cultures of both land and water governance were sketched. These different cultural imprints of the two main actors determine to a high degree the established planning culture. The added value of a cultural perspective is, first of all, to state that culture matters, even in planning processes where legal bases, standardized instruments and Europeanwide assessments play an important role. However, sometimes it is even the cultural embeddedness of management processes that makes them work, or, as Peter Drucker is supposed to have claimed, 'Culture eats strategy for breakfast and technology for lunch [...]' (as cited in Fields, 2006). Second, the possibility that considering the cultural perspectives of planning can lead to a further understanding of planning processes, decision-making and cooperation. Called the 'black box of integration', it is still not empirically analysed how planners integrate different aspects and how they can come to a deeper understanding of the cooperation-partner logic. The cultural analysis of planning processes is based on individual to organizational phenomena, on all kinds of levels with special regard to their cultural implementation and imprint. Methodologically entering new ground, the analysis of cultural aspects of planning processes is largely unexplored, as culture is omnipresent, not able to be isolated, and becomes evident in nearly all aspects, which discourages many researchers. On the other hand, the possibility for a deeper understanding of planning processes is there. As a final note, it should be mentioned that, of course, considering a cultural perspective does not lead to the possibility of steering planning processes though culture. As Schein (2003) has outlined already, culture is not a means of steering: only the consequences of culture can be handled and managed. This is an important fact, as culture and its consequences have to be understood and comprehended before one is in a position to manage it. 


\section{Notes}

1. IWRM has been defined by the Global Water Partnership (2000) as 'a process which promotes the coordinated development and management of water, land and related resources, in order to maximize the resultant economic and social welfare in an equitable manner without compromising the sustainability of vital ecosystems' (p. 22). This approach is often used by water management research projects, and sometimes by environmental science researchers, but less frequently in spatial planning. In the context of this article, IWRM is associated with an integrative claim of riverscape development, but in a much broader field (as water resources include much more than just rivers).

2. Referring to the (critical) discussions about a coastal manager (Billé, 2008) or a landscape manager (Pryce, 1991), a river manager is not per se desirable, either. The strong point of interest behind such an institution is to foster the integration process in a formal way instead of accepting a multilayered system typical for its complex allocation of roles.

\section{References}

Benz, A., Lütz, S., Schimank, U., \& Simonis, G. (2007). Handbuch Governance: Theoretische Grundlagen und empirische Anwendungsfelder. Wiesbaden, Germany: Verlag für Sozialwissenschaften.

Billé, R. (2008). Integrated coastal zone management: Four entrenched illusions. S.A.P.I. EN.S, 1(2), 75-86.

Biswas, A. K. (2004). Integrated water resources management: A reassessment. Water International, 29(2), 248-256. doi:10.1080/02508060408691775

DiGaetano, A., \& Strom, E. (2003). Comparative urban governance: An integrated approach. Urban Affairs Review, 38(3), 356-395. doi:10.1177/1078087402238806

Driessen, P. P. J., Dieperink, C., van Laerhoven, F., Runhaar, H. A. C., \& Vermeulen, W. J. V. (2012). Towards a conceptual framework for the study of shifts in modes of environmental governance - experiences from The Netherlands. Environmental Policy and Governance, 22(3), 143-160. doi:10.1002/eet.1580

Einig, K. (2012), Evaluation in der Regionalplanung. Informationen zur Raumentwicklung, 1/2.2012, I-IV.

Ernste, H. (2012). Framing cultures of spatial planning. Planning Practice \& Research, 27(1), 87-101. doi:10.1080/02697459.2012.661194

Faust, T. (2002). Organisationskultur und Ethik Perspektiven für öffentliche Verwaltungen. Berlin, Germany: TENEA.

Friedmann, J. (2005). Planning cultures in transition. In B. Sanyal (Ed.), Comparative planning cultures (pp. 29-44). New York, NY: Routledge.

Fürst, D. (2001). Regional governance - ein neues Paradigma der Regionalwissenschaften? Raumforschung und Raumordnung, 59(5-6), 370-380. doi:10.1007/BF03183038

Fürst, D. (2007). Planungskultur: Auf dem Weg zu einem besseren Verständnis von Planungsprozessen? PNDonline, III/2007. Retrieved from http://www.planung-neu-denken.de/ images/stories/pnd/dokumente/pndonline3-2007-fuerst.pdf

Gleick, P. H. (2000). A look at twenty-first century water resources development. Water International, 25(1), 127-138. doi:10.1080/02508060008686804

Global Water Partnership. (2000). TAC background Papers No.4: Integrated water resources management. Stockholm, Sweden: Global Water Partnership.

Gullestrup, H. (2009). Theoretical Reflections on Common European (Planning-)Cultures. In J. Knieling \& F. Othengrafen (Eds.), Planning cultures in Europe: Decoding cultural Phenomena in urban and regional planning. London, UK: Ashgate Publishing.

Hartmann, T. (2010). Reframing polyrational floodplains: Land policy for large areas for temporary emergency retention. Nature and Culture, 5(1), 15-30. doi:10.3167/nc.2010.050102

Healey, P. (1996). The communicative turn in planning theory and its implications for spatial strategy formations. Environment and Planning B: Planning and Design, 23(2), 217-234. doi: $10.1068 / \mathrm{b} 230217$

Hutter, G. (2007). Strategic planning for long-term flood risk management: Some suggestions for learning how to make strategy at regional and local level. International Planning Studies, 12(3), 
Knieling, J., \& Othengrafen, F. (2009). En route to a theoretical model for comparative research on planning cultures. In J. Knieling \& F. Othengrafen (Eds.), Planning cultures in Europe: Decoding cultural phenomena in urban and regional planning. London, UK: Ashgate Publishing.

Levin-Keitel, M., \& Sondermann, M. (2014), Planerische Instrumente in lokalen Kontexten Einblicke in die Vielfalt von Planungskulturen. Arbeitsbericht der ARL, 10, 172-191.

Levin-Keitel, M. (2014). Flusslandschaften in der Stadt. RaumPlanung, 172(1-2014), 20-25.

Mitchell, B. (2005). Integrated water resource management, institutional arrangements, and land-use planning. Environment and Planning A, 37(8), 1335-1352. doi:10.1068/a37224

Molle, F. (2008). Nirvana concepts, narratives and policy models: Insights from the water sector. Water Alternatives, 1(1), 131-156.

Moss, T. (2009), Zwischen Ökologisierung des Gewässerschutzes und Kommerzialisierung der Wasserwirtschaft: Neue Handlungsanforderungen an Raumplanung und Regionalpolitik. Raumforschung und Raumordnung, 67, 54-68. doi:10.1007/BF03183143

Nuissl, H., \& Heinrichs, D. (2011). Fresh wind or hot air - does the governance discourse have some-thing to offer to spatial planning? Journal of Planning Education and Research, 31(1), 47-59. doi:10.1177/0739456X10392354

Nuissl, H. (2008). Umfrage zur 'Planungskultur'. PNDonline, I/2008. Retrieved from http://www. planung-neu-denken.de/images/stories/pnd/dokumente/pndonline\%204\%202007_umfrage.pdf

Othengrafen, F. (2012). Uncovering the unconscious dimensions of planning. Using culture as a tool to analyse spatial planning practices. Farnham, UK: Ashgate Publishing.

Pryce, S. (1991). Community control of landscape management. Planning Outlook, 34(2), 75-82. doi:10.1080/00320719108711896

Reimer, M., \& Blotevogel, H. H. (2012). Comparing spatial planning practice in Europe: A plea for cultural sensitization. Planning Practice \& Research, 27(1), 7-24. doi:10.1080/ 02697459.2012 .659517

Rittel, H. W. J., \& Webber, M. M. (1973). Dilemmas in a general theory of planning. Policy Sciences, 4(2), 155-169. doi:10.1007/BF01405730

Scharpf, F. W. (2000). Interaktionsformen: Akteurzentrierter Institutionalismus in der Politikforschung. Opladen, Germany: Leske + Budrich.

Schein, E. H. (2003). Organisationskultur: The Ed Schein Corporate Culture Survival Guide. Bergisch Gladbach, Germany: EHP.

Stadt Nürnberg. (2012a). Nürnberg in Zahlen 2012. Amt für Stadtforschung und Statistik für Nürnberg und Fürth, Nürnberg.

Stadt Nürnberg. (2012b). Integriertes Stadtentwicklungskonzept Nürnberg am Wasser. Wirtschaftsreferat, Amt für Wohnen und Stadtentwicklung, Nürnberg.

Stadt Regensburg. (2012). Regensburg in Zahlen. Ausgabe 2012. Amt für Stadtentwicklung, Abteilung Statistik, Regensburg.

United Nations Educational, Scientific and Cultural Organisation. (2014). World Heritage List. The old town of Regensburg with Stadtamhof. Retrieved from http://www.whc.unesco.org/en/list/ 1155

Von Haaren, C., \& Moss, T. (2011). Voraussetzungen für ein integriertes Management: Koordination und Kooperation der wasserrelevanten Akteure und Organisationen in Deutschland. In C. Von Haaren, \& C. Galler, (Eds.), Zukunftsfähiger Umgang mit Wasser im Raum (pp. 67-81). Hannover, Germany: Akademie für Raumforschung und Landesplanung.

Wasserwirtschaftsamt Regensburg (WWA) und Stadt Regensburg. (2010). Hochwasserschutz Stadt Regensburg. Flussraumkonzept Donau - Regen. Regensburg.

Weith, T. (2007). Anforderungen an Evaluationen von Umbauaktivitäten in Städten und Regionen. In T. Weith, (Ed.), Stadtumbau erfolgreich evaluieren (pp. 237-252). Münster, Germany: Waxmann Verlag. 
Wiering, M., \& Immink, I. (2006). When water management meets spatial planning: A policyarrangements perspective. Environment and Planning C: Government and Policy, 24(3),

423-438. doi:10.1068/c0417j

\section{Legal frameworks}

Baugesetzbuch (BauGB) in der Fassung vom 23.09.2004 (BGB1. I S. 2414) zuletzt geändert durch Gesetz vom 11.06.2013 (BGBl. I 2005, 1548).

Directive 2007/60/EC of the European Parliament and of the Council of 23 October 2007 on the assessment and management of flood risks (Flood Directive).

Gesetz zur Ordnung des Wasserhaushalts 2010 (Wasserhaushaltsgesetz) (WHG) vom 31. Juli 2009 (BGBl. I 2009, 2585). 